\title{
Keragaan Penampilan Lima Genotip Sorgum Manis (Sorghum Bicolor (L.) Moench) Introduksi Jepang Di Jatinangor Indonesia
}

\author{
Phenotypic Variability of Five Sweet Sorghum from Japan \\ at Jatinangor Indonesia
}

\author{
Anas $^{1}$ dan Agus Suhanto ${ }^{1}$ \\ ${ }^{\prime}$ Laboratorium Pemuliaan Tanaman, Fakultas Pertanian Universitas Padjadjaran \\ Jl. Raya Bandung Sumedang Km.21 Jatinangor, Bandung
}

\begin{abstract}
Sorghum (Sorghum bicolor (L.) Moench) is a multi-beneficial plant that can be used as food, feed, and energy by the types and the extensive use. This study aims to examine the performance of the appearance of five sweet sorghum genotypes (Sorghum bicolor (L.) Moench) from the selection of sweet sorghum introduced from Japan and the opportunity to be developed and used as genetic material in subsequent breeding programs. The field experiment was carried out in the experimental station of the Faculty of Agriculture, Padjadjaran University, Jatinangor, Sumedang Regency, West Java. Altitude is around 754 meters above sea level (asl) and has type $\mathrm{C}$ rainfall (slightly wet) based on Schmidt and Ferguson classification, and Inceptisol soil types. The experimental design used a randomized complete block design with five sweet sorghum genotypes as a treatment and repeated five times. The results showed that the appearance of five sweet sorghum genotypes introduced from Japan was quite diverse, especially for the characteristics of yield components. Some genotypes show early maturity and differences in length of seed filling period. These characters will affect the yield of sugar content in the sorghum stem. Taomitsu and Super Sugar were suitable for high yield components. However, genotypic variability for all characters is narrow even though the heritability is generally high for almost all characters. This fact shows the need for increased diversity through crossing or mutation to make it easier to get high genetic advances for the characters to be improved.
\end{abstract}

Keywords: phenotypic variability, sweet sorghum

\begin{abstract}
Abstrak: Sorgum (Sorghum bicolor (L.) Moench) adalah tanaman multimanfaat yang dapat digunakan sebagai pangan, pakan dan energi sesuai dengan jenis dan pemanfaatanya yang sangat banyak. Penelitian ini bertujuan menguji keragaan penampilan lima genotip sorgum manis (Sorghum bicolor (L.) Moench) hasil seleksi dari sorgum manis introduksi asal Jepang dan peluang untuk dikembangkan dan digunakan sebagai materi genetik dalam program pemuliaan selanjutnya. Percobaan lapang dilaksanakan di kebun percobaan Fakultas Pertanian Universitas Padjadjaran Jatinangor Kabupaten Sumedang, Jawa Barat. Ketinggian tempat sekitar 754 meter di atas permukaan laut (dpl), dan mempunyai curah hujan tipe C (agak basah) berdasarkan klasifikasi Schmidt dan Ferguson, serta jenis tanah Inceptisol. Penelitian menggunakan Rancangan Acak Kelompok dengan lima genotype sorgum manis sebagai perlakukan dan diulang lima kali. Hasil penelitian memperlihatkan penampilan lima genotipe sorgum manis hasil introduksi dari Jepang cukup beragam terutama untuk karakter komponen hasil. Beberapa genotipe memperlihatkan umur genjah dan perbedaan lama periode pengisian biji. Hal ini akan mempengaruhi hasil gula dalam batang sorgum. Taomitsu dan Super Sugar berpenampilan baik untuk komponen hasil. Namun demikian variabilitas genotipik untuk semua karakter sempit meskipun heritabilitasnya secara umum tinggi hampir untuk semua karakter. Hal ini memperlihatkan perlunya peningkatan keragaman baik melalui persilangan atau mutasi untuk mempermudah mendapatkan kemajuan genetic yang tinggi untuk karakter-karakter yang akan ditingkatkan.
\end{abstract}

Kata kunci: Variabilitas fenotipe, Sorgum manis

\section{Pendahuluan}

Sorgum (Sorghum bicolor (L.) Moench) adalah tanaman multimanfaat yang dapat digunakan sebagai pangan, pakan dan energy sesuai dengan jenis dan pemanfaatanya yang sangat banyak (Anas 2016; Anas et al. 2015). Sorgum bukan tanaman baru di Indonesia dan telah dikenal di berbagai daerah dengan nama yang berbeda-beda.

Sorgum merupakan tanaman serealia yang potensial untuk dibudidayakan dan dikembangkan, khususnya pada daerah-daerah marginal dan kering di Indonesia. Potensi lahan kering yang sangat luas di Indonesia, sangat cocok untuk dikembangkan 
tanaman sorgum yang lebih toleran terhadap kekeringan dibandingkan tanaman serealia lainnya (Anas 2016). Keunggulan sorgum terletak pada daya adaptasi agroekologi yang luas, toleran terhadap kekeringan, memerlukan biaya lebih sedikit dalam budidayanya serta lebih tahan terhadap serangan hama dan penyakit.

Salah satu jenis sorgum yang dapat dimanfaatkan sebagai pakan dan sumber energi terbarukan adalah sorgum manis (sweet sorghum) yang batangnya dapat menyimpan gula (Pei et al. 2010; Anas \& Yoshida 2004b). Kandungan gula dalam batang sorgum manis cukup tinggi yaitu 76\%-78\% hampir sama dengan kandungan gula dalam tebu yang mencapai 68\%-80\% (Tsuchihashi \& Goto 2005). Sorgum manis berpotensi untuk dapat dikembangkan sebagai penghasil tetes gula pengganti tanaman tebu. Dengan berbagai keunggulan sorgum manis seperti yang telah disebutkan di atas, maka sorgum manis dapat dijadikan sebagai alternatif pengganti tebu untuk bahan dasar pembuatan MSG (Tsuchihashi \& Goto 2004; Tsuchihashi \& Goto 2005). Di berbagai negara telah lama memanfaatkan sorgum manis sebagai penghasil ethanol (Nan et al. 1994).

Selain pemanfaatan sorgum manis sebagai penghasil ethanol, sorgum manis juga dimanfaatkan sebagai pakan ternak dan telah banyak dimanfaatkan di beberapa negara (Phukoetphim et al. 2017; Ekefre et al. 2017). Namun demikian pemanfaatan sorgum manis baik sebagai pakan maupun penghasil gula/energi di Indonesia masih sangat sedikit dan pemanfaatan hanya terbatas sebagai tanaman sela dan digunakan sebagai pangan. Jenis varietas yang ditanam oleh petani juga sangat terbatas.

Kebanyakan penelitian sorgum di Indonesia masih pada pemanfaatannya sebagai pangan dan bagaimana cara memperluas peluang penanamannya di lahan-lahan kering yang pada umumnya merupakan tanah masam (Anas et al. 2015; Anas 2011; Anas et al. 2019). Pada tahun 2004 telah diteliti peluang budidaya sorgum manis di lahan kering Madura dan pemanfaatan sorgum manis sebagai pengganti tetes tebu di Indonesia (Tsuchihashi \& Goto 2004).

Untuk memperbesar peluang pemanfaatan dan pemilihan jenis sorgum manis yang cocok ditanam di Indonesia, maka perlu pengujian penampilan beberapa jenis sorgum manis hasil seleksi dari sorgum introduksi asal Jepang. Untuk itu penelitian ini bertujuan menguji keragaan penampilan lima genotip sorgum manis (Sorghum bicolor (L.) Moench) hasil seleksi dari sorgum manis introduksi asal Jepang dan peluang untuk dikembangkan dan digunakan sebagai materi genetik dalam program pemuliaan selanjutnya.

\section{Bahan dan Metode}

Percobaan lapang dilaksanakan di kebun percobaan Program D-III Agribisnis Fakultas Pertanian Universitas Padjadjaran Jatinangor Kabupaten Sumedang, Jawa Barat. Ketinggian tempat sekitar 754 meter di atas permukaan laut (dpl), dan mempunyai curah hujan tipe C (agak basah) berdasarkan klasifikasi Schmidt dan Ferguson, jenis tanah Inceptisol.

Materi genetik yang digunakan dalam percobaan ini adalah lima sorgum manis turunan dari sorgum hasil introduksi dari Jepang yaitu Wray, Keller, Big Sugar Sorgo, Taomitsu, dan Super Sugar. Metode penelitian yang digunakan yaitu metode eksperimen dengan Rancangan Acak Kelompok (RAK) dengan lima genotip sebagai perlakuan yang diulang lima kali dan ditanam dalam plot baris (row plot). Jarak tanam yang digunakan adalah $10 \mathrm{~cm}$ jarak tanaman dalam baris dan $80 \mathrm{~cm}$ jarak antar baris.

Tanaman dipupuk dengan menggunakan $90 \mathrm{~kg}$ $\mathrm{N}$ ha $^{-1}$, $50 \mathrm{~kg} \mathrm{P}_{2} \mathrm{O}_{5} \mathrm{ha}^{-1}$ and $35 \mathrm{~kg} \mathrm{~K}_{2} \mathrm{O} \mathrm{ha}{ }^{-1}$. Pupuk nitrogen diberikan dua kali yaitu $1 / 3$ pada waktu tanam bersamaan dengan pupuk fosfor dan kalium, sisanya 2/3 pupuk Nitrogen diberikan setelah tanaman berumur satu bulan. Pupuk diberikan dengan cara dibuat larikan sejauh $\pm 7-15 \mathrm{~cm}$ sebelah kanan dan kiri dari lubang tanam.

Pengamatan meliputi morfologi tanaman yang terdiri dari jumlah daun, tinggi tanaman $(\mathrm{cm})$, panjang dan diameter batang $(\mathrm{cm})$, bobot batang $(\mathrm{g})$, jumlah buku, waktu keluarnya malai (hst), lama pengisian biji (hari setelah antesis sampai panen) dan pengamatan komponen hasil yaitu bobot malai (g), panjang malai (cm), bobot 1000 biji (g), bobot biji malai $^{-1}(\mathrm{~g})$.

Analisis statistik meliputi uji $\mathrm{F}$ dan dilanjutkan dengan Uji Jarak Berganda Duncan untuk melihat perbedaan penampilan dari masing-masing perlakuan untuk semua karakter yang diamati, analisis varians fenotipik dan genotipik serta nilai duga heritabilitas.

\section{Hasil dan Pembahasan}

\section{Kondisi lingkungan tumbuh}

Distribusi curah hujan selama percobaan tidak merata. Jumlah curah hujan sebesar 210,08 $\mathrm{mm} /$ bulan dan rata-rata curah hujan harian 15,28 $\mathrm{mm} /$ hari. Distribusi hujan yang cukup tinggi pada awal pertanaman cukup menunjang untuk perkecambahan sorgum manis. Selama percobaan berlangsung rata-rata temperatur sebesar $28,19^{\circ} \mathrm{C}$ dengan kelembaban udara rata-rata adalah 57,51\%. Suhu yang cukup tinggi dan kelembaban yang 
sedang akan mempengaruhi proses fisiologis tanaman, terutama proses transpirasi akan meningkat.

Rata-rata intensitas cahaya matahari selama percobaan adalah sebesar 44873,89 lux. Menurut Bull et al. (1972) tingkat fotosintetik yang tinggi pada tanaman tebu terjadi pada saat banyak cahaya. Hal ini juga akan mempengaruhi pergerakan cairan dalam xylem. Pada akhir masa pertumbuhan memasuki musim kemarau sehingga intensitas cahaya berkisar antara 29000-58000 lux. Dengan intensitas cahaya matahari yang tinggi, maka proses fotosintesis dalam tanaman diharapkan akan meningkat.

\section{Keragaman penampilan tanaman sorgum manis}

Secara umum semua karakter yang diamati dalam penelitian ini memperlihatkan perbedaan yang nyata berdasarkan uji $\mathrm{F}$ pada taraf 5\% (Tabel 1). Hal ini memperlihatkan keragaman fenotipe untuk semua karakter yang diamati dari lima genotipe sorgum manis yang diuji. Karakter bobot malai dan bobot biji.malai ${ }^{-1}$ memperlihatkan nilai koefisien varians (KV) yang relative cukup tinggi (Tabel 1). Hal ini disebabkan karena pada akhir pertanaman, serangan hama burung cukup tinggi dan terdapat beberapa genotipe sorgum manis yang sangat disukai burung.

Terdapat pengaruh morfologi dan kandungan kimia pada biji sorgum terhadap kesukaan burung terhadap biji sorgum manis. Malai yang lebih terbuka dengan sekan yang hamper menutupi biji cenderung tidak disukai oleh burung (Askham 1988). Selain itu kandungan tannin yang tinggi pada biji sorgum juga mempengaruhi kesukaan burung terhadap biji sorgum.

Terdapat perbedaan jenis malai diantara lima genotipe sorgum manis yang diuji dalam penelitian ini. Kemungkinan juga terdapat perbedaan kandungan tannin biji sorgum untuk masing-masing genotipe sorgum manis yang diuji. Terdapat tiga penggolangan tanaman sorgum berdasarkan kandungan tannin ini (Askham 1988). Golongan I yang tidak mengandung testa/tanin adalah golongan sorgum yang paling banyak disukai oleh burung.

Selain bobot biji dan malai yang memperlihatkan variasi yang sangat besar, bobot batang juga memperlihatkan kisaran variasi yang tinggi diantara lima genotipe sorgum manis yang diuji (183,65 384,67). Pengaruh ketersediaan air selama pertumbuhan sorgum manis sangat mempengaruhi bobot dari batang sorgum manis (Tsuchihashi \& Goto 2005). Pertanaman pada musim kemarau dengan kondisi tidak banyak air batang sorgum manis akan memperpendek jarak antar buku dan hal ini yang menyebabkan bobot batang yang lebih ringan dibandingkan dengan bobot batang sorgum manis pada pertanaman musim hujan.

Dari hasil uji Duncan menunjukkan genotip Keller dan Wray berpenampilan superior untuk jumlah daun (Tabel 2). Genotip Wray memiliki jumlah daun yang paling banyak yaitu \pm 16 daun dan genotip Super Sugar memiliki jumlah daun yang paling sedikit yaitu \pm 14 daun.

Jumlah daun ini akan mempengaruhi proses fotosientesis dan jumlah asimilat yang dihasilkan tanaman. Salah satu faktor yang mempengaruhi banyaknya hasil fotosintesis adalah luas daun. Luas daun tergantung dari jumlah dan ukuran daun. Maka semakin banyak daun, cenderung semakin besar pula hasil fotosintesis yang didapatkan (Bull et al. 1972). Jumlah daun ini sejalan dengan jumlah buku pada batang tanaman sorgum manis. Wray dan Keller juga memperlihatkan jumlah buku yang berbeda nyata dibandingkan dengan yang lainnya (Tabel 2).

Dari hasil pengamatan tinggi tanaman genotipe Keller menunjukkan penampilan yang superior dibandingkan genotipe lainnya. Hal ini konsisten dengan jumlah daun dan buku yang juga lebih banyak dibandingkan yang lainnya. Genotipe Wray meskipun memperlihatkan jumlah buku dan daun yang banyak, tapi tinggi tanamannya tidak memperlihatkan perbedaan dengan genotype lainnya. Hal ini memperlihatkan panjang ruas antar buku genotype Wray lebih pendek dibandingkan Keller. Penelitian yang dilakukan Tsuchihashi \& Goto (2005) memperlihatkan bahwa genotype Wray mengalami pemendekan ruas antar buku pada pertanaman musim kemarau di Madura. Hal ini memperlihatkan juga bahwa penampilan batang genotipe Wray kemungkinan lebih peka terhadap lingkungan dibandingkan genotipe Keller.

Fungsi batang antara lain adalah sebagai transportasi materi yaitu air dan mineral dari akar melalui xylem dan fotosintat dari daun melalui floem serta tempat menyimpan cadangan makanan. Bahan yang ditransport dalam floem utamanya adalah bahan yang diproduksi dalam kloroplas. Pengisian bahan terlarut (fotosintat) ke dalam floem akan meningkatkan tekanan pada pembuluh tapis yang bertanggung jawab terhadap terjadinya aliran massa. Proses pengisian dan pengurangan pada floem berpengaruh terhadap status air pada pembuluh tapis. Oleh karena itu akumulasi sukrosa pada pembuluh tapis akan terkait dengan 
Tabel. 1. Nilai Min, Max, Rata-rata, F-Hitung dan Koefisien Variasi untuk karakter-karakter yang diamati

\begin{tabular}{|c|c|c|c|c|c|c|c|}
\hline No & Karakter & Genotip elit & Min & $\operatorname{Max}$ & Rata-rata & Fhit & $\mathbf{K V}$ \\
\hline \multirow[t]{5}{*}{1} & \multirow[t]{5}{*}{ Jumlah Daun } & Wray & 18 & 15 & 16,57 & \multirow[t]{5}{*}{$23.44^{*}$} & \multirow[t]{5}{*}{2.66} \\
\hline & & Taomitsu & 16 & 14 & 14,88 & & \\
\hline & & Super Sugar & 16 & 14 & 14,69 & & \\
\hline & & Big Super Sorgo & 17 & 14 & 15,11 & & \\
\hline & & Keller & 18 & 16 & 16,32 & & \\
\hline \multirow[t]{5}{*}{2} & \multirow{5}{*}{$\begin{array}{l}\text { Tinggi Tanaman } \\
(\mathrm{cm})\end{array}$} & Wray & 260 & 172 & 231,00 & \multirow[t]{5}{*}{$7,19^{*}$} & \multirow[t]{5}{*}{6.26} \\
\hline & & Taomitsu & 293 & 190 & 252,28 & & \\
\hline & & Super Sugar & 230 & 170 & 216,00 & & \\
\hline & & Big Super Sorgo & 279 & 141 & 240,91 & & \\
\hline & & Keller & 297 & 170 & 265,36 & & \\
\hline \multirow[t]{5}{*}{3} & \multirow{5}{*}{$\begin{array}{l}\text { Panjang Batang } \\
(\mathrm{cm})\end{array}$} & Wray & 198 & 75 & 168,23 & \multirow[t]{5}{*}{$6.18 *$} & \multirow[t]{5}{*}{9.25} \\
\hline & & Taomitsu & 223 & 146 & 182,56 & & \\
\hline & & Super Sugar & 163 & 101 & 143,62 & & \\
\hline & & Big Super Sorgo & 208 & 54 & 178,17 & & \\
\hline & & Keller & 224 & 103 & 195,08 & & \\
\hline \multirow[t]{5}{*}{4} & \multirow{5}{*}{$\begin{array}{l}\text { Diameter Batang } \\
(\mathrm{cm})\end{array}$} & Wray & 2,4 & 1,6 & 1,96 & \multirow[t]{5}{*}{$16.50^{*}$} & 6.90 \\
\hline & & Taomitsu & 2,2 & 1,4 & 1,79 & & \\
\hline & & Super Sugar & 1,7 & 1,1 & 1,40 & & \\
\hline & & Big Super Sorgo & 2,0 & 1,2 & 1,70 & & \\
\hline & & Keller & 2,1 & 1,4 & 1,65 & & \\
\hline 5 & Bobot Batang & Wray & 585 & 115 & 384,67 & $10.13^{*}$ & 16.89 \\
\hline & $(\mathrm{g})$ & Taomitsu & 530 & 60 & 285,86 & & \\
\hline & & Super Sugar & 295 & 70 & 183,65 & & \\
\hline & & Big Super Sorgo & 420 & 125 & 275,00 & & \\
\hline & & Keller & 505 & 225 & 355,20 & & \\
\hline 6 & Jumlah Buku & Wray & 12 & 9 & 10,10 & $22.45^{*}$ & 6.43 \\
\hline & & Taomitsu & 9 & 6 & 7,96 & & \\
\hline & & Super Sugar & 9 & 6 & 7,42 & & \\
\hline & & Big Super Sorgo & 9 & 6 & 7,78 & & \\
\hline & & Keller & 11 & 8 & 9,44 & & \\
\hline 7 & Pengisian biji (hari setelah & Wray & 43 & 27 & 31,33 & $42.15^{*}$ & 6.27 \\
\hline & & Taomitsu & 50 & 43 & 46,24 & & \\
\hline & & Super Sugar & 42 & 36 & 40,08 & & \\
\hline & & Big Super Sorgo & 44 & 35 & 39,87 & & \\
\hline & & Keller & 34 & 22 & 31,40 & & \\
\hline 8 & Waktu keluar malai & Wray & 83 & 62 & 76,53 & $30,38 *$ & 4.06 \\
\hline & (hst) & Taomitsu & 68 & 55 & 60,12 & & \\
\hline & & Super Sugar & 69 & 55 & 66,15 & & \\
\hline & & Big Super Sorgo & 71 & 58 & 65,35 & & \\
\hline & & Keller & 82 & 70 & 73,40 & & \\
\hline 9 & Bobot Malai & Wray & 84,45 & 30,32 & 47,92 & $6,38 *$ & 27.34 \\
\hline & $(\mathrm{g})$ & Taomitsu & 115,34 & 21,43 & 69,08 & & \\
\hline & & Super Sugar & 52,00 & 10,34 & 27,44 & & \\
\hline & & Big Super Sorgo & 194,67 & 34,53 & 75,91 & & \\
\hline & & Keller & 84,20 & 32,14 & 56,03 & & \\
\hline 10 & Panjang Malai & Wray & 83 & 24 & 57,57 & $17.12 *$ & 4.98 \\
\hline & $(\mathrm{cm})$ & Taomitsu & 82 & 65 & 71,72 & & \\
\hline & & Super Sugar & 86 & 60 & 72,35 & & \\
\hline & & Big Super Sorgo & 87 & 48 & 67,83 & & \\
\hline & & Keller & 77 & 65 & 69,96 & & \\
\hline 11 & Bobot 1000 biji & Wray & 17,39 & 11,83 & 14,07 & $81,30^{*}$ & 6.08 \\
\hline & $(\mathrm{g})$ & Taomitsu & 31,34 & 19,56 & 24,14 & & \\
\hline & & Super Sugar & 16.69 & 16.07 & 17,41 & & \\
\hline & & Big Super Sorgo & 26.73 & 19.81 & 22,25 & & \\
\hline & & Keller & 15.96 & 13.45 & 14,62 & & \\
\hline 12 & Bobot Biji per malai & Wray & 50,56 & 13,47 & 28,53 & $9.17 *$ & 31,55 \\
\hline & $(\mathrm{g})$ & Taomitsu & 96,34 & 11,35 & 53,98 & & \\
\hline & & Super Sugar & 40,65 & 3,24 & 17,69 & & \\
\hline & & Big Super Sorgo & 30,34 & 24,65 & 58,90 & & \\
\hline & & Keller & 71,64 & 22,91 & 42,78 & & \\
\hline
\end{tabular}

Keterangan : * berbeda nyata dengan Ftabel pada taraf 5\%. 
Tabel 2. Hasil Uji Duncan Pada karakter-Karakter Yang Diamati

\begin{tabular}{|c|c|c|c|}
\hline No & Karakter & Genotip elit & Rata-rata \\
\hline \multirow[t]{5}{*}{1} & Jumlah Daun (buah) & Super Sugar & $14,67 \mathrm{a}$ \\
\hline & & Taomitsu & $14,90 \mathrm{ab}$ \\
\hline & & Big Super Sorgo & $15,24 \mathrm{~b}$ \\
\hline & & Keller & $16,43 \mathrm{c}$ \\
\hline & & Wray & $16,57 \mathrm{c}$ \\
\hline & Tinggi Tanaman $(\mathrm{cm})$ & Super Sugar & $216,14 \mathrm{a}$ \\
\hline & & Wray & $231,00 \mathrm{a}$ \\
\hline & & Big Super Sorgo & $233,24 \mathrm{ab}$ \\
\hline & & Taomitsu & $252,56 \mathrm{bc}$ \\
\hline & & Keller & $260,97 \mathrm{c}$ \\
\hline \multirow[t]{5}{*}{3} & Panjang Batang $(\mathrm{cm})$ & Super Sugar & $143,75 \mathrm{a}$ \\
\hline & & Keller & $164,82 \mathrm{~b}$ \\
\hline & & Big Super Sorgo & $168,23 \mathrm{bc}$ \\
\hline & & Taomitsu & $179,63 \mathrm{bc}$ \\
\hline & & Wray & $190,07 \mathrm{c}$ \\
\hline \multirow[t]{5}{*}{4} & Diameter Batang $(\mathrm{cm})$ & Super Sugar & $1,38 \mathrm{a}$ \\
\hline & & Keller & $1,64 \mathrm{~b}$ \\
\hline & & Big Super sorgo & $1,70 \mathrm{~b}$ \\
\hline & & Taomitsu & $1,77 \mathrm{~b}$ \\
\hline & & Wray & $1,96 \mathrm{c}$ \\
\hline \multirow[t]{5}{*}{5} & Berat Batang $(\mathrm{g})$ & Super Sugar & $190,10 \mathrm{a}$ \\
\hline & & Big Super Sorgo & $271,00 \mathrm{~b}$ \\
\hline & & Taomitsu & $301,50 \mathrm{bc}$ \\
\hline & & Keller & $342,67 \mathrm{~cd}$ \\
\hline & & Wray & $374,73 \mathrm{~d}$ \\
\hline \multirow[t]{5}{*}{6} & Jumlah Buku (buah) & Super Sugar & 7,46 a \\
\hline & & Big Super Sorgo & $7,66 \mathrm{a}$ \\
\hline & & Taomitsu & 7,97 a \\
\hline & & Keller & $9,37 \mathrm{~b}$ \\
\hline & & Wray & $10,10 \mathrm{~b}$ \\
\hline \multirow[t]{5}{*}{7} & Pengisian biji (hsa) & Keller & $29,90 \mathrm{a}$ \\
\hline & & Wray & $31,33 \mathrm{~b}$ \\
\hline & & Big Super Sorgo & $39,91 \mathrm{~b}$ \\
\hline & & Super Sugar & $40,01 \mathrm{c}$ \\
\hline & & Taomitsu & $46,37 \mathrm{c}$ \\
\hline \multirow[t]{5}{*}{8} & Waktu keluar malai (hst) & Keller & 59,93 a \\
\hline & & Wray & $66,05 \mathrm{~b}$ \\
\hline & & Big Super Sorgo & $66,71 \mathrm{~b}$ \\
\hline & & Super Sugar & $74,83 \mathrm{c}$ \\
\hline & & Taomitsu & $76,53 \mathrm{c}$ \\
\hline \multirow[t]{5}{*}{9} & Bobot Malai (g) & Super Sugar & 32,04 a \\
\hline & & Wray & $47,92 \mathrm{ab}$ \\
\hline & & Keller & $57,26 \mathrm{bc}$ \\
\hline & & Big Super Sorgo & $73,18 \mathrm{c}$ \\
\hline & & Taomitsu & $74,28 \mathrm{c}$ \\
\hline \multirow{5}{*}{\multicolumn{2}{|c|}{$10 \quad$ Panjang Malai $(\mathrm{cm})$}} & Wray & $57,57 \mathrm{a}$ \\
\hline & & Big Super Sorgo & $68,08 \mathrm{~b}$ \\
\hline & & Keller & $70,65 \mathrm{bc}$ \\
\hline & & Super Sugar & $72,36 \mathrm{bc}$ \\
\hline & & Taomitsu & $72,93 \mathrm{c}$ \\
\hline \multirow{5}{*}{\multicolumn{2}{|c|}{11 Bobot 1000 biji $(\mathrm{g})$}} & Wray & $14,09 \mathrm{a}$ \\
\hline & & Keller & 14,66 a \\
\hline & & Super Sugar & $17,49 \mathrm{~b}$ \\
\hline & & Big Super Sorgo & $22,09 \mathrm{c}$ \\
\hline & & Taomitsu & $24,41 \mathrm{~d}$ \\
\hline \multirow{5}{*}{\multicolumn{2}{|c|}{12 Bobot Biji per malai $(\mathrm{g})$}} & Super Sugar & 24,15 a \\
\hline & & Wray & $28,53 \mathrm{ab}$ \\
\hline & & Keller & $39,47 \mathrm{bc}$ \\
\hline & & Big Super Sorgo & $55,52 \mathrm{c}$ \\
\hline & & Taomitsu & $60,08 \mathrm{c}$ \\
\hline
\end{tabular}

Keterangan: nilai rata-rata yang diikuti huruf yang sama pada kolom yang sama untuk masing-masing karakter menunjukkan tidak berbeda nyata menurut Uji Jarak Berganda Duncan pada taraf 5\% 
penyerapan air oleh proses osmosis dan turgornya akan naik. Sebaliknya bila terjadi pengurangan sukrosa dari pembuluh tapis maka akan terjadi penurunan konsentrasi bahan terlarut (meningkatkan osmotik potensial) dan karenanya juga menurunkan kadar air (Bull et al. 1972). Diameter batang yang besar memungkinkan fotosintat yang tersimpan dalam batangpun menjadi lebih banyak. Genotipe Super Sugar dan Taomitsu memperlihatkan sifat dalam dibandingkan dengan genotipe lainnya. Periode pengisia biji Taomitsu lebih lama dibandingkan dengan genotipe yang lebih genjah. Hal ini kemungkinan karena sink (panjang malai) dari Taomitsu secara nyata lebih panjang dibanding genotipe genjah Wray atau Keller (Tabel 1 dan 2). Genotip Keller dan Wray periode pengisian biji paling singkat dibandingkan genotipe lainnya, sehingga hasil biji secara umum lebih sedikit dibandingkan yang lainnya. Hal ini selain karena sink yang kecil yaitu pangjang malai dan biji Wray dan Keller yang nyata lebih kecil dibandingkan yang lainnya.

Periode pengisian biji erat kaitannya dengan akumulasi gula dalam batang sorgum. Dengan demikian lama pendeknya periode pengisian biji akan menentukan kandungan gula dalam batang sorgum manis. Pada Wray, Keller dan Rio, periode maksimum pengsisian biji maksimum tercapai pada 26 hari setelah antesis (hsa) (Tsuchihashi \& Goto 2004). Pengisian tercepat terjadi pada 12 hsa dan hal ini mengakibatkan perubahan asimilat yang ada di batang untuk pembentukan biji. Namun demikian total bobot gula meningkat tajam setelah antesis sampai mencapai maksimum pada 22 hsa untuk Wray dan 33 hsa untuk Keller (Tsuchihashi \& Goto 2004).

\section{Variabilitas Fenotipik dan Genotipik Tanaman Sorgum Manis}

Semua karakter-karakter maofologi maupun komponen hasil yang diamati memperlihatkan variabilitas fenotipik yang luas, kecuali untuk karakter periode pengisian biji, waktu berbunga dan bobot 100 biji (Tabel 3). Rata-rata kelima genotype sorgum manis memperlihatkan penampilan yang relative seragam untuk karakter-karakter ini.

Namun demikian variabilitas genotipik untuk semua karakter yang diamati adalah sempit. Variabilitas genotipik suatu karakter akan bervariasi tergantung faktor genetik dan lingkungan. Variabilitas genotipik merupakan parameter penting dalam pengembangan suatu genotip terutama menentukan keefektifan dalam proses seleksi (Allard 1999). Latar belakang genetik kelima genotipe sorgum manis yang semuanya berasal dari Jepang, menyebabkan sempitnya variabilitas genotipik untuk semua karakter yang diamati. Genotipe atau kultivar tanaman yang di muliaakan atau dikembangkan di tempat yang sama selama bertahun-tahun cenderung akan memiliki kesamaan genetik (Anas \& Yoshida 2004a; Anas \& Yoshida 2004b).

Menurut Crowder (1997) variabilitas genetik yang luas akan memberikan variabilitas fenotipik yang luas pula, jika interaksi genotip dan lingkungan cukup tinggi. Variabilitas genetik yang sempit menunjukkan bahwa latar belakang genetik dari populasi ini relatif seragam. Menurut Murray et al. (2009) jenis sorgum manis yang ada di dunia berasal dari tiga golongan besar yaitu kafir, caudatum, dan tipe-tipe bicolor.

Suatu karakter dikategorikan luas apabila nilai varians genetiknya lebih besar dibandingkan dua kali nilai standar deviasi varians genetiknya, dan dikatakan sempit apabila sebaliknya (Baihaki dan Daradjat, 1987 dikutip Pinaria et al. 1995). Jika populasi yang diuji berasal dari tetua dengan latar belakang genetik yang berbeda, maka variabilitas genetik dalam populasi tersebut akan lebih besar dari pada populasi yang berasal dari tetua yang berkerabat dekat (Fehr 1987). Variabilitas genetik dan variabilitas fenotipik yang luas sangat memudahkan program pemuliaan dalam pemilihan bahan tetua untuk perakitan varietas baru.

Namun demikian variabilitas genotipik yang sempit didukung oleh nilai duga heritabilitas yang tinggi pada semua karakter yang diamati. Pada karakter-karakter yang memiliki nilai heritabilitas yang tinggi seleksi akan berlangsung efektif dan efisien, karena pengaruh faktor lingkungan sangat kecil sehingga faktor genetik lebih dominan dalam penampilan tanaman. Heritabilitas adalah suatu parameter genetik yang mengukur sampai sejauh mana penampilan suatu genotip disebabkan oleh faktor genetik dan lingkungan (Sleper \& Poehlman 2006).

Meskipun variabilitas genetik pada percobaan kali ini sempit, namun variabilitas fenotipiknya luas untuk semua karakter yamg diamati (Tabel 3). Variabilitas sempit dengan variabilitas fenotipik yang luas menunjukkan bahwa variasi pada penampilan fenotipe lima genotipe sorgum manis lebih disebabkan oleh faktor lingkungan dibandingkan faktor genetiknya. 
Tabel 3. Variabilitas Genotipik dan Fenotipik Serta Heritabilitas Karakter-Karakter Yang Diamati.

\begin{tabular}{|c|c|c|c|c|c|c|c|c|c|}
\hline \multirow{2}{*}{ No. } & \multirow{2}{*}{ Karakter } & \multicolumn{3}{|c|}{ Variabilitas Genotipik } & \multicolumn{3}{|c|}{ Variabilitas Fenotipik } & \multicolumn{2}{|c|}{ Heritabilitas } \\
\hline & & $\sigma_{\mathrm{g}}^{2}$ & $2 \mathrm{Sd} \sigma_{\mathrm{g}}^{2}$ & Kriteria & $\sigma_{\mathrm{f}}^{2}$ & $2 \mathrm{Sd} \sigma_{\mathrm{f}}^{2}$ & Kriteria & $\mathrm{h}^{2}$ & Kriteria \\
\hline 1. & Jumlah daun & 0,77 & 0,93 & Sempit & 0,94 & 0,93 & Luas & 0,82 & Tinggi \\
\hline 2 & Tinggi tanaman & 276,82 & 372,47 & Sempit & 500,41 & 371,28 & Luas & 0,55 & Tinggi \\
\hline 3. & Panjang batang & 253,99 & 351,45 & Sempit & 499,27 & 349,93 & Luas & 0,51 & Tinggi \\
\hline 4. & Diameter batang & 0,44 & 0,05 & Sempit & 0,06 & 0,05 & Luas & 0,76 & Tinggi \\
\hline 5. & Berat batang & 4561,97 & 5854,23 & Sempit & 7060,61 & 5844,74 & Luas & 0,65 & Tinggi \\
\hline 6. & Jumlah buku & 1,29 & 1,55 & Sempit & 1,59 & 1,55 & Luas & 0,81 & Tinggi \\
\hline 7. & Periode pengisian biji & 45,51 & 53,84 & Sempit & 51,04 & 53,83 & Sempit & 0,89 & Tinggi \\
\hline 8. & Waktu berbunga & 45,76 & 54,65 & Sempit & 53,55 & 54,65 & Sempit & 0,85 & Tinggi \\
\hline 9. & Berat malai & 305,90 & 411,71 & Sempit & 553,41 & 410,38 & Luas & 0,52 & Tinggi \\
\hline 10 & Panjang malai & 37,34 & 45,82 & Sempit & 48,93 & 45,80 & Luas & 0,76 & Tinggi \\
\hline 11 & Bobot 1000 biji & 20,56 & 24,03 & Sempit & 21,85 & 24,03 & Sempit & 0,94 & Tinggi \\
\hline 12. & Bobot biji per malai & 283,27 & 366,42 & Sempit & 450,62 & 365,74 & Luas & 0,62 & Tinggi \\
\hline 13. & Kandungan gula & 4,63 & 6,41 & Sempit & 9,12 & 6,39 & Luas & 0,51 & Tinggi \\
\hline
\end{tabular}

\section{Kesimpulan}

Penampilan lima genotipe sorgum manis hasil introduksi dari Jepang cukup beragam terutama untuk karakter komponen hasil. Beberapa genotipe memperlihatkan umur genjah dan perbedaan lama periode pengisian biji. Hal ini akan mempengaruhi hasil gula dalam batang sorgum. Taomitsu dan Super Sugar berpenampilan baik untuk komponen hasil. Namun demikian variabilitas genotipik untuk semua karakter sempit meskipun heritabilitasnya secara umum tinggi hamper untuk semua karakter. Hal ini memperlihatkan perlunya peningkatan keragaman baik melalui persilangan atau mutasi untuk mempermudah mendapatkan kemajuan genetic yang tinggi untuk karakter-karakter yang akan ditingkatkan.

\section{Daftar Pustaka}

Allard, R.W., 1999. Principles of Plant Breeding 2nd ed., John Wiley \& Sons.

Anas, 2011. Development of White Sorghum as a Base for the Development of Flour-Based Food Products. In Prosiding Seminar Nasional Integratif Pangan, Kesehatan dan Lingkungan - Pemanfaatan Sumber Daya Lokal Untuk Ketersediaan Pangan dan Kesehatan Masyarakat. Bandung: Jurusan Kimia Fakultas MIPA Universitas Padjadjaran. Available at: https://www.researchgate.net/publication/32374586 1.

Anas et al., 2019. Genetic gain of $\mathrm{Al}$ tolerance and contribution of agronomic traits on $\mathrm{Al}$ tolerance in the early stage of sorghum breeding program. Plant
Production Science, $\mathrm{OO}(\mathrm{OO})$, pp.1-8. Available at: https://www.tandfonline.com/doi/full/10.1080/134 3943X.2019.1569471.

Anas, Rachmadi, M. \& Mansyur, 2015. Phenotypic and Genotypic Variance and Heritability of Stay Green Character Among 22 Elite Sorghum (Sorghum bicolor (L.) Moench) Genotypes. KnE Life Sciences, 2(1), pp.318-325. Available at: https://knepublishing. com/index.php/Kne-Life/article/view/166.

Anas \& Yoshida, T., 2004a. Genetic Diversity among Japanese Cultivated Sorghum Assessed with Simple Sequence Repeats Markers. Plant Production Science, 7(2), pp.217-223.

Anas \& Yoshida, T., 2004b. Sorghum diversity evaluated by simple sequence repeat (SSR) markers and phenotypic performance. Plant Production Science, 7(3), pp.301-308.

Anas, Z., 2016. SORGUM - Tanaman Multimanfaat 1 st ed. M. Rachmadi, ed., Bandung: Unpad Press.

Askham, L.R., 1988. Proceedings of the Thirteenth Vertebrate Pest Conference (1988). In Specialist.

Bull, T. a, Gayler, K.R. \& Glasziou, K.T., 1972. Lateral movement of water and sugar across xylem in sugarcane stalks. Plant physiology, 49(6), pp.10071011.

Crowder, L.V., 1997. Genetika Tumbuhan Terjemahan. Sutarso, ed., Yogyakarta: Gadjah Mada University Press.

Ekefre, D.E. et al., 2017. Evaluation of three cultivars of sweet sorghum as feedstocks for ethanol production in the Southeast United States. Heliyon, 3(12), p.e00490. Available at: http://dx.doi.org/10.1016/ j.heliyon.2017.e00490.

Fehr, W., 1987. Principles of Cultivar Development. Theory and Technique Vol.1, New York: Macmillan Publishing Company. 
Murray, S.C. et al., 2009. Sweet Sorghum Genetic Diversity and Association Mapping for Brix and Height. The Plant Genome Journal, 2(1), p.48. Available at: https://www.crops.org/publications/tpg/abstracts/ 2/1/48.

Nan, L., Best, G. \& Neto, C.C.D.C. eds., 1994. Integrated Energy Systems In China-The Cold Notheastern Region Experience 1st ed., Viale delle Terme di Caracalla, o0100 Rome, Italy: FAO United Nation. Available at: http://www.fao.org/docrep/T4470E/T4470Eoo.ht m.

Pei, Z. et al., 2010. Genetic diversity of elite sweet sorghum genotypes assessed by SSR markers. Biologia Plantarum, 54(4), pp.653-658. Available at: http://link.springer.com/10.1007/s 10535-010-0116$\mathrm{x}$ [Accessed February 3, 2018].

Phukoetphim, N. et al., 2017. Improvement of ethanol production from sweet sorghum juice under batch and fed-batch fermentations: Effects of sugar levels, nitrogen supplementation, and feeding regimes. Electronic Journal of Biotechnology, 26, pp.84-92. Available http://dx.doi.org/10.1016/j.ejbt.2017.01.005.

Pinaria, A. et al., 1995. Variabilitas Genetik dan Heritabilitas Karakter Biomassa 53 Genotip Kedelai. Zuriat, 6(2).

Sleper, D.A. \& Poehlman, J.M., 2006. Breeding Field Crops Fifth., 2121 State Avenue, Iowa: Blackwell Publishing.

Tsuchihashi, N. \& Goto, Y., 2004. Cultivation of Sweet Sorghum (Sorghum bicolor (L.) Moench) and Determination of its Harvest Time to Make Use as the Raw Material for Fermentation, Practiced during Rainy Season in Dry Land of Indonesia. Plant Production Science, 7(October 2003), pp.442-448.

Tsuchihashi, N. \& Goto, Y., 2005. Internode Characteristics of Sweet Sorghum (Sorghum bicolor (L.) Moench) during Dry and Rainy Seasons in Indonesia. Plant Production Science, 8(5), pp.601-607. 